Volume 15. Nomor 1. June 2020 Page 13-25
Pandecta
http://journal.unnes.ac.id/nju/index.php/pandecta

\title{
Relasi Kekuasaan Antar Presiden dan Wakil Presiden dalam Sistem Ketatanegaraan Republik Indonesia
}

\author{
Hananto Widodo', Dicky Eko Prasetio², Fradhana Putra Disantara ${ }^{3}$ \\ 1,2,3Fakultas IImu Sosial dan Hukum, Universitas Negeri Surabaya, Indonesia \\ DOI: http://dx.doi.org/10.15294/pandecta.v15i1.24554
}

\begin{abstract}
Article info
Abstrak

Article History:

Received : May 222019

Relasi kekuasaan antar Presiden dan Wakil Presiden dalam sistem ketatanegaraan Indonesia selama ini dapat dikatakan selalu mengalami pasang surut. Persoalan ini disAccepted: May 302020 Published: June 152020 ebabkan pengaturan kewenangan Wakil Presiden dalam UUD NRI Tahun 1945 tidak jelas. Penelitian ini bertujuan untuk menganalisis implikasi yuridis dari kekaburan

Keywords:

relasi; kekuasaan; presiden; wakil presiden kewenangan Wakil Presiden serta memberikan rekomendasi ke depan bagaimana seyogyanya kewenangan Presiden dan Wakil Presiden dapat diatur dan dilaksanakan secara proporsional. Penelitian ini merupakan penelitian hukum normatif dengan bahan hukum primer berupa UUD NRI 1945 dan bahan hukum sekunder berupa buku dan artikel jurnal berkaitan dengan kewenangan Wakil Presiden. Dari penelitian ini dapat disimpulkan bahwa pengoptimalan kewenangan Wakil Presiden dapat dilakukan dengan mengaturnya di dalam Undang-Undang Lembaga Kepresidenan

relations; power; president; vice president yang diharapkan dapat membagi secara proporsional kewenangan Presiden dan Presiden diatur secara pasti dalam aturan hukum supaya tidak tergantung pada praktik ketatanegaraan serta faktor non hukum, yaitu faktor politik. Mengingat pentingnya fungsi Wakil Presiden dalam sistem ketatanegaraan Republik Indonesia maka alangkah baiknya, Undang-Undang Lembaga Kepresidenan yang mengatur mengenai pembagian wewenang antar Presiden dan Wakil Presiden segera dibentuk.
\end{abstract}

\begin{abstract}
The power relations between the President and Vice President in the Indonesian constitutional system so far can be agreed to always overcome the ups and downs. The 1945 Constitution of the Republic of Indonesia is unclear. This study aims to analyze the juridical implications of the obscurity of the Vice President's authority and give approval to the front regarding the authority of the President and Vice President to be able to regulate and implement proportionality. This research is a normative legal research with primary legal material in the form of the 1945 Constitution of the Republic of Indonesia and secondary legal material containing books and journal articles about the authority of the president's representative. From this research it can be concluded that optimizing the authority of the Vice President can be done with a license in the Law on Presidential Institutions which is expected to allocate proportional authority to the powers of the President and Vice President. Therefore, it is hoped that the Vice President's licensing can be regulated in regulating legislation not dependent on state administration and non-legal factors, namely political factors. Considering the importance of the function of the Vice President in the constitutional system of the Republic of Indonesia, it would be nice, the Law on Presidential Institutions governing the distribution of powers between the President and the Vice President was immediately formed.
\end{abstract}




\section{Pendahuluan}

Kajian mengenai relasi kekuasaan di negara dengan sistem presidensial biasanya lebih difokuskan pada relasi antara lembaga eksekutif dan legislatif (Arsil, 2017). Kajian ini sangat wajar, sebab dalam sistem ketatanegaraan manapun di dunia ini, relasi kekusaaan secara kelembagaan seringkali difokuskan pada relasi antara keluasaan eksekutif dan legislatif. Kuatnya kajian relasi secara kelembagaan antara eksekutif dan legislatif karena eksekutif dan legislatif merupakan organ utama (main organ) jika diletakkan dalam konteks ajaran pemisahan kekuasaan. Di samping relasi antara kekuasaan eksekutif dan legislatif sebenarnya ada relasi kekuasaan lain yang tidak kalah menariknya untuk dikaji, yakni relasi antar kekuasaan Presiden dan Wakil Presiden.

Secara struktur kelembagaan negara antara Presiden dan Wakil Presiden memang berada dalam satu struktur kelembagaan negara, yakni lembaga Kepresidenan, apalagi mereka merupakan pasangan calon yang dipilih dalam satu paket, baik ketika dipilih melalui Majelis Permusyawaratan Rakyat atau ketika mereka dipilih langsung oleh rakyat. Namun demikian, dalam praktik ketatanegaraan selama ini, relasi kekuasaan antar Presiden dan Wakil Presiden selalu mengalami pasang surut. Pada periode tertentu Wakil Presiden bisa menjalankan perannya secara maksimal, tetapi di periode yang lain, Wakil Presiden tidak bisa menjalankan perannya secara maksimal. Hal ini disebabkan secara konstitusional kewenangan Wakil Presiden dapat dikatakan tidak jelas serta belum ada pengaturan secara expressive verbis dalam peraturan perundang-undangan.

Dalam UUD NRI Tahun 1945 kewenangan Wakil Presiden hanya dikatakan sebagai pembantu Presiden. Oleh karena itu, Jabatan Wakil Presiden hanya memiliki pseudo-authority (kewenangan semu) yang kewenangannya bergantung sepenuhnya pada jabatan Presiden sebagai kepala negara sekaligus sebagai kepala pemerintahan. Presiden sebagai kepala negara dan kepala pemerintahan seolah-olah lebih superior dibandingkan dengan Wakil Presiden (Syaputra, 2018) Hal ini dilandasi bahwa jabatan Wakil Presiden seolah-olah dianggap sebagai "ban serep", atau istilah lainnya hanya sebagai presidential complementary. Padalah, seperti yang diketahui, bahwa Presiden dan Wakil Presiden secara legitimasi politik sama-sama dibentuk dalam satu pasangan oleh partai/gabungan partai politik sesuai dengan amanat konstitusi.

Presiden dan Wakil Presiden jika ditilik dalam legitimasi politiknya merupakan samasama pilihan langsung rakyat dalam satu pasang (Triono, 2017). Oleh karena itu, karena merupakan pilihan rakyat secara langsung dalam satu pasang sudah semestinya terdapat pembagian kewenangan yang saling mengimbangi. Hal ini dilandasi oleh sebuah prinsip yang menyatakan bahwa een bevoegdheid (macht) zender veraantwoordelijkheid. Dengan demikian, maka setiap jabatan haruslah dapat dipertanggungjawabkan sebagai konsekuensi dari kewenangan yang diterima. Aspek pertanggungjawaban diperlukan sebagai upaya untuk menilai apakah suatu kewenangan sudah dijalankan dengan baik apa belum (Reformulasi et al., 2019). Hal itu juga berlaku bagi jabatan Presiden dan Wakil Presiden. Dengan demikian, maka kewenangan yang dimiliki harusnya berbanding lurus dengan legitimasinya.

UUD NRI 1945 hanya menyatakan bahwa kedudukan dan tugas Wakil Presiden hanya sebatas presidential complamantary dari sistem presidensial yang ada. Hal tersebut dapat ditinjau pada Pasal 4 Ayat (2) UUD NRI 1945 yang menyatakan "Dalam melakukan kewajibannya Presiden dibantu oleh satu orang Wakil Presiden" serta Pasal 8 ayat (1) UUD NRI yang menyatakan "Jika Presiden mangkat, berhenti, diberhentikan, atau tidak dapat melakukan kewajibannya dalam masa jabatannya, ia digantikan oleh Wakil Presiden sampai habis masa jabatannya". Meskipun begitu, justru dengan adanya hal tersebut dapat menimbulkan problematika terkait kewenangan Wakil Presiden. Dengan demikian, kewenangan Wakil Presiden masih sangat kabur dan rentan memiliki kedudukan yang lebih inferior disbanding jabatan Presiden itu sendiri. Bahkan, legitimasi poli- 
tik Wakil Presiden justru dikhawatirkan tidak memberikan dampak yang signifikan, melihat kasus pada era pemerintahan 2009-2014 dan 2019-2024 jabatan Wakil Presiden yang tidak secara langsung diisi oleh kader partai politik. Praktisnya, posisi Wakil Presiden sangat rentan untuk 'goyah' dengan adanya konflik internal partai politik pengusung Presiden dan Wakil Presiden yang telah terpilih.

Penelitian mengenai kewenangan Wakil Presiden sebagaimana yang dilakukan oleh Nyoman Mas Aryani dan Bagus Hermanto (2018) tentang Rekonstruksi Kejelasan Kedudukan Wakil Presiden Dalam Kerangka Penguatan Dan Penegasan Sistem Presidensiil Indonesia yang menegaskan bahwa tidak jelasnya kewenangan Wakil Presiden membuat tidak proporsional kewenangan di lembaga kepresidenan (Nyoman Mas Aryani, 2018). Presiden dengan berbagai kewenangan yang ada seolah menempatkan Wakil Presiden sebagai "assistance" bagi Presiden. Dengan demikian Wakil Presiden hanya bertindak sebagai pengganti Presiden dalam kegiatankegiatan seremonial saja. Hal ini juga diperkuat oleh penelitian yang dilakukan oleh Dewi Mulyanti (2018) tentang Rekonstruksi Jabatan Wakil Presiden Dalam Ketatanegaraan Di Indonesia (Tinjauan Perbandingan Hukum Negara Amerika Serikat, Cina Dan Filipina) (Mulyanti, 2018) bahwa jika dibandingkan dengan beberapa negara dengan sistem presidensial, maka kewenangan Wakil Presiden di Indonesia masih dikatakan lemah dan belum jelas. Dibandingkan dengan dua penelitian terdahulu di atas,, penelitian ini lebik berfokus pada menilik relasi Presiden dan Wakil Presiden serta pada orientasinya adalah optimalisasi kewenangan Wakil Presiden. Selain itu, penelitian ini juga meruntut secara historis kewenangan yang pernah dilakukan oleh Wakil Presiden dari Moh. Hatta hingga Ma'ruf Amin. Dengan demikian, dapat disimpulkan bahwa penelitian ini berbeda dengan dua penelitian sebelumnya.

Kewenangan dan kedudukan Wakil Presiden harus menemui titik terang, atau setidaknya selaras dengan nilai-nilai proses pada tahapan Pemilu yang telah dilakukan oleh rakyat yang telah memberikan legitima- si, legalitas, dan kredibilitas terhadap para pejabat publik. Pemilu yang telah melahirkan legitimasi yang kuat dari masyarakat tidak boleh diciderai dengan 'kabur'-nya kedudukan dan kewenangan Wakil Presiden. Konsekuensi logis dari sistem pemerintahan saat ini sebenarnya menghendaki adanya keterlibatan Presiden secara aktif pada setiap penyelenggaran negara dalam ranah eksekutif. Oleh karena itu, tulisan ini berusaha untuk merekonstruksikan kewenangan Wakil Presiden yang harus lebih dioptimalkan dikaitkan dengan legitimasi politik Wakil Presiden yang sama-sama dipilih secara langsung dalam satu pasang oleh rakyat.

\section{Metode}

Penelitian ini merupakan penelitian normatif atau normative legal research (Marzuki, 2017). Penelitian ini menggunakan tiga pendekatan, yaitu pendekatan perundanganundangan (statute approach), pendekatan konseptual (conceptual approach) dan pendekatan historis (historical approach). Pendekatan perundang-undangan digunakan untuk mengkaji peraturan perundang-undangan yang pernah mengatur kewenangan Wakil Presiden. Pendekatan konseptual digunakan untuk mengkaji kewenangan Wakil Presiden dalam sistem pemerintahan di Indonesia, sedangkan pendekatan historis digunakan untuk melacak sejarah ketatanegaraan terkait kewenangan Wakil Presiden. Bahan hukum primer adalah UUD NRI Tahun 1945. Bahan hukum sekunder adalah jurnal dan buku. Bahan hukum yang terkumpul akan dianalisis secara preskriptif analitik (Marzuki, 2017).

\section{Hasil Penelitian dan Pembahasan}

\section{Relasi Presiden dan Wakil Presiden dalam Sejarah Ketatanegaraan Indonesia}

Berdirinya Negara Kesatuan Republik Indonesia pada tanggal 17 Agustus 1945 tentunya tidak selalu menemui jalan mulus dalam perkembangannya. Berbagai aral dan problematika memang seharusnya diselesaikan dengan cukup baik, termasuk dengan keberanian membangun berbagai struktur kelangkapan negara. Salah satu unsur kelengkapan negara yang dibangun adalah adanya 
jabatan Presiden dan Wakil Presiden. Meski secara konstitusional jabatan Presiden dan Wakil Presiden dibentuk oleh Majelis Permusyawaratan Rakyat yang notabene merupakan pelaksana kedaulatan rakyat, namun karena kondisi negara yang masih dihinggapi suasana revolusi kemerdekaan maka untuk pertama kalinya jabatan Presiden dan Wakil Presiden dipilih secara aklamasi oleh PPKI (Fuqoha, 2018). Dalam pemilihan secara aklamasi oleh PPKI tersebut, terpilihlah nama Soekarno sebagai Presiden dan Moh. Hatta sebagai Wakil Presiden (Haris, 2019). Dengan terpilihnya Presiden dan Wakil Presiden Indonesia pertama tersebut, maka dimulailah Pemerintahan Indonesia yang baru merdeka pada 17 Agustus 1945.

Pada awal pemerintahan Presiden Soekarno dan Wakil Presiden Moh. Hatta, tepatnya pada tanggal 16 Oktober 1945 dikeluarkanlah Maklumat Wakil Presiden No. X tanggal 16 Oktober Tahun 1945. Isi dari Maklumat Wakil Presiden No. X tersebut adalah bahwa Komite Nasional yang dibentuk pada tanggal 29 Agustus 1945 yang pada awalnya sebagai bagian dari lembaga eksekutif kemudian diubah kedudukannya sebagai lembaga legislatif (R. A. B. Kusuma, 2011). Maklumat yang dikeluarkan oleh Wakil Presiden Moh. Hatta itu sejatinya menimbulkan dua polemik (R. A. B. Kusuma, 2011). Pertama, secara tidak langsung dikeluarkannya Maklumat No. $X$ tersebut telah mengubah UUD 1945 yang seharusnya perubahan tersebut dilakukan oleh MPR. Kedua, diragukan juga kewenangan Wakil Presiden apakah dapat membuat suatu maklumat (dan atau keputusan yang bersifat mengatur). Namun, terkait dengan dua polemik di atas, serta melihat kondisi ketatanegaraan yang belum stabil Maklumat Wakil Presiden No. X tanggal 16 Oktober Tahun 1945 diterima secara "legowo" oleh Presiden Soekarno dan MenteriMenteri yang sedang menjabat saat itu.

Maklumat Wakil Presiden No. X tanggal 16 Oktober Tahun 1945 benar-benar memberikan dampak yang signifikan dalam sistem pemerintahan Indonesia. Tak cukup di situ, Wakil Presiden Moh.Hatta pada tanggal 3 November 1945 juga menandatangani se- buah Maklumat Pemerintah yang isinya mendukung eksistensi partai politik dalam sistem pemerintahan Indonesia (Thoha, 2014). Ditandatanganinya Maklumat Pemerintah oleh Wakil Presiden Moh. Hatta dikarenakan bahwa Presiden Soekarno pada waktu itu sedang ada kunjungan di luar negeri. Dampak dengan ditandatanganinya Maklumat Pemerintah tertanggal 3 November 1945 adalah semakin menjamurnya Partai Politik sebagai upaya pemerintah untuk merangkul berbagai golongan "aliran" politik dalam mempertahankan kemerdekaan Indonesia. Munculnya dua maklumat yang ditandatangani oleh Wakil Presiden yaitu Maklumat Wakil Presiden No. X tanggal 16 Oktober Tahun 1945 dan tertanggal 3 November 1945 menunjukkan bahwa sejatinya Wakil Presiden juga memiliki kewenangan yang besar dalam mengurusi penyelenggaraan pemerintahan, terutama jika dikaitkan dengan kondisi negara yang pada saat itu belum stabil.

Romantisme "dwitunggal" SoekarnoHatta akhirnya runtuh dengan ketidaksepakatan antarkedua tokoh yang sekaligus menjabat sebagai Presiden dan Wakil Presiden. Presiden Soekarno akhirnya menjadi one man show dengan menjalankan sendiri roda pemerintahan tanpa dibantu oleh seorang Wakil Presiden, karena semenjak 1 Desember 1956 Wakil Presiden Moh. Hatta menyatakan mengundurkan diri. Pengunduran diri Moh.Hatta sebagai Wakil Presiden menyebabkan Presiden Soekarno semakin leluasa untuk mewujudkan "Demokrasi Terpimpin" (Siregar, 2018)' yang dicita-citakannya meski pun pada akhirnya "Demokrasi Terpimpin" juga menimbulkan otoritarianisme demokrasi. Dalam tinjauan ketatanegaraan, terjadinya otoritarianisme demokrasi dalam pelaksanaan "Demokrasi Terpimpin" bisa disebabkan karena tidak adanya jabatan Wakil Presiden sehingga Presiden sehingga komando pemerintahan cukup dilakukan oleh Presiden saja serta dinamika politik yang berkembang pada waktu itu hingga membuat Presiden mengeluarkan Dekret Presiden 5 Juli 1959. Pada akhirnya "Demokrasi Terpimpin" yang dijalankan secara otoriter pada akhirnya tumbang setelah dekeluarkannya Ketetapan MPRS No. XXXIII/MPRS/1967 tentang Pen- 
cabutan Kekuasaan Pemerintahan Negara dari Presiden Soekarno yang disebabkan pidato pertanggungjawabannya yang berjudul "Nawaksara" atas persitiwa G30 S PKI tidak diterima oleh Majelis Permusyawaratan Rakyat (Melania M.I. Wongkar, 2016)Emerald Publishing Limited. Purpose: This paper examines the influence of three dimensions of customer knowledge management - knowledge from customer, knowledge for customer and knowledge about customer - on innovation capabilities (speed and quality. Dengan demikian, diangkatlah Soeharto sebagai Presiden Republik Indonesia menggantikan Soekarno.

Diangkatnya Soeharto sebagai Presiden Republik Indonesia menggantikan Soekarno, tentunya mengawali dinamika pemerintahan yang sering disebut sebagai orde baru (Marijan, 2019). Soeharto dengan orde baru nya memiliki komitmen untuk melaksanakan Pancasila secara murni dan konsekuen selain juga untuk meningkatkan perekonomian negara salah satunya dengan memperbaiki hubungan dengan blok barat yang sempat rapuh di masa Pemerintahan Soekarno. Dalam relasi antara Presiden dan Wakil Presiden pada masa orde baru, pengangkatan Soeharto sebagai Presiden melalui Ketetapan MPRS Nomor IX/MPRS/1966 yang diangkat oleh Majelis Permusyawaratan Rakyat Sementara (selanjutnya disebut dengan MPRS) sebagai pejabat Presiden Republik Indonesia melalui Ketetapan MPRS Nomor XXXIII/MPRS/1967 tidak disebutkan secara eksplisit terkait kedudukan Pejabat Wakil Presiden. Sehingga, tidak ada pengangkatan Pejabat Wakil Presiden. Pejabat Presiden akan bertanggung jawab serta tunduk kepada MPRS. Hal ini dapat dipahami karena selain baru saja mengalami peristiwa G30 S PKI, Indonesia juga harus mencari pengganti Presiden Soekarno untuk sesegera mungkin. Hal ini bertujuan untuk menghindari vaccum of power atau kekosongan kekuasaan jabatan Presiden. Oleh karena itu, jabatan Presiden Soeharto yang menggantikan Presiden Soekarno memang hanya bersifat "sementara" karena jika negara sudah dalam situasi yang kondusif, maka dapat dilakukan pemilihan umum untuk memilih Presiden dan Wakil Presiden.
Presiden Soeharto diangkat kembali menjadi mandataris MPR atau Presiden Republik Indonesia melalui TAP MPR Nomor IX/MPR/1973 tahun 1973 tentang Pengangkatan Presiden Republik Indonesia. Indonesia kembali memiliki figur yang duduk dalam jabatan Wakil Presiden setelah diangkatnya Sultan Hamengkubuwono IX melalui TAP MPR Nomor XI/MPR/1973 tahun 1973. Sultan Hamengkubuwono IX dikenal memilliki andil besar atas beberapa negoisasi terkait utang negara serta upaya guna menarik para investor untuk masuk ke Indonesia pada masa masa-masa awal Orde Baru. Alasan Sri Sultan menghendaki posisi Wakil Presiden adalah dirinya mendukung perjuangan demokratisasi bangsa ala Presiden Soeharto. Akan tetapi, manakala Sri Sultan menduduki posisi Wakil Presiden selama lima tahun, peran Sri Sultan tidak begitu banyak didengar publik. Sri Sultan hanya memiliki sedikit tanggung jawab yang tidak memiliki daya kuasa atas apa apa yang menjadi tanggung jawabnya. Berbagai kebijakan pemerintah langsung diputuskan oleh Presiden Soeharto tanpa adanya pertimbangan Sri Sultan (Atmakusumah, 2011). Bahkan, pengangkatan Sri Sultan hanyalah sebagai kamuflase agar kesan militeristik dalam tata kepemerintahan tidak terlihat. Fenomena inilah yang menimbulkan istilah banserep bagi jabatan Wakil Presiden.

Fenomena banserep berlanjut pada era pemerintahan Presiden Soeharto 19781983. Presiden Soeharto diangkat kembali sebagai Presiden Republik Indonesia oleh MPR melalui TAP MPR Nomor X/MPR/1978. Wakil Presiden yang menjabat kala itu adalah Adam Malik, yang diangkat sebagai Wakil Presiden oleh MPR melalui TAP MPR Nomor XI/MPR/1978. Adam Malik merupakan eks menteri luar negeri sekaligus pernah menjabat pula sebagai Wakil Perdana Menteri Urusan Sosial Politik. Pada saat menjabat menteri luar negeri mengalami tren yang signifikan. Hal itu ditunjukkan dengan memperbaiki hubungan Indonesia dengan Malaysia, andil dalam pembentukan ASEAN, dan lain sebagainya. Namun, peran dan tanggung jawab Adam Malik pada saat menduduki kursi Wakil Presiden juga sangat terbatas. 
Adam Malik hanya diperintahkan oleh Presiden untuk melakukan tugas pengawasan secara nasional tanpa adanya kekuasan untuk melakukan suatu perbuatan atau kebijakan, serta mengelola terkait urusan negara dalam bidang hubungan luar negeri. Suatu hal kontroversial yang pernah dilakukan oleh Adam Malik adalah memberikan dorongan guna dibukanya kembali hubungan diplomatik Indonesia dengan Republik Rakyat Cina (Fiky Arista, 2017) . Akan tetapi, hal ini menemui jalan buntu manakala Presiden Soeharto hanya akan membuka hubungan diplomatik dengan batasan-batasan tertentu.

Setelah kejadian itu, pria yang menjadi salah satu pendiri Kantor Berita Antara ini akhirnya lebih memilih bersikap untuk memiliki pendapat yang sama atas kebijakan maupun narasi politik yang dibangun oleh Presiden Soeharto. Hal tersebut merupakan implikasi kuatnya legitimasi politik dari Presiden Soeharto yang menyebabkan tugas dan kewenangan Wakil Presiden selalu bergantung pada Presiden. Era kepemerintahan Presiden Soeharto berlanjut lima tahun kemudian, yakni periode 1983-1988. Presiden Soeharto diangkat sebagai Presiden oleh MPR yang keempat kalinya secara berturut-turut melalui TAP MPR Nomor VI/MPR/1983 tentang Pengangkatan Presiden Republik Indonesia. Pada periode ini yang menjabat sebagai Wakil Presiden adalah Umar Wirahadikusumah yang diangkat melalui TAP MPR Nomor VIII/ MPR/1983 tentang Pengangkatan Wakil Presiden Republik Indonesia.Eks Kepala staf TNI Angkatan Darat 1969-1973 dan Badan Pemeriksa Keuangan tahun 1973-1983 ini merupakan Wapres pertama dari kalangan ABRI. Disinyalir, latar belakang terpilihnya Umar sebagai Wapres merupakan salah satu bentuk 'balas budi' dari Presiden Soeharto atas peristiwa G30S PKI (Susanto, 2017). Di samping itu, pengangkatan Umar sebagai Wapres berperan untuk menenangkan kondisi kala itu, khususnya manakala Presiden Soeharto sedang bermasalah dengan beberapa purnawirawan dan tokoh sipil yang kritis terhadap pemerintaha. Pengangkatan Umar merupakan suatu bentuk narasi politik pemerintah guna memberikan gambaran bahwa kondisi hubungan Presiden dan purnawirawan ada- lah baik-baik saja. Pada era kali ini kekuasaan Presiden tetap sangatlah dominan daripada Wakil Presiden. Wakil Presiden hanya melakukan tugas dan kewenangannya dalam hal-hal seremonial negara. Meskipun begitu, Wapres Umar telah memperkenalkan istilah pengawasan melekat, pengawasan fungsional, dan pengawasan masyarakat guna menunjang jalannya pemerintahan pada aspek pengawasan dalam skala nasional.

Tajuk kekuasaan dan kekuatan politik Presiden Soeharto berlanjut pada periode 1988-1993. Presiden Soeharto diangkat oleh MPR menjadi Presiden untuk kelima kalinya melalui TAP MPR Nomor V/MPR/1988 tentang Pengangkatan Presiden Republik Indonesia, sedangkan Sudharmono diangkat melalui TAP MPR Nomor VII/MPR/I988 tentang Pengangkatan Wakil Presiden Republik Indonesia. Sudharmono adalah Wapres kedua yang berasal dari kalangan militer. Sudarmono memiliki andil dalam penumpasan G30S PKI. Pada era ini, Wapres tetaplah hanya bertugas pada aspek-aspek seremonial semata, seperti menyiapkan sistem sidang presidium kabinet atau sidang-sidang kabinet atas petunjuk Presiden Soeharto.

Eks Sekretaris Presidium dan Sekretaris Negara ini, juga hanya melanjutkan fungsi pengawasan yang pernah dilakukan oleh Wapres sebelumnya. Pada era ini, tromol pos 5000 dibuka guna memudahkan masyarakat untuk memberikan laporan atas hal-hal yang bersifat administrasi maupun non-administrasi kepada pemerintah. Sudarmono juga acapkali melakukan kunjungan kerja pada setiap provinsi, setiap departemen, pada kantor menteri-menteri negara, dan departemen non pemerintah untuk berkoordinasi terkait aspek pengawasan (Suwirta, 2018) Meskipun begitu, segala hal yang dilakukan oleh wapres harus berdasarkan pada perintah presiden Soeharto, atau atas izin dari Presiden Soeharto. Hal yang tidak jauh berbeda juga terjadi pada masa kepemimpinan Soeharto selanjutnya (1993-1998) dengan Wakil Presiden Tri Sutrisno selain juga bertugas sebagai pengawas pelaksana pemerintahan, mengganti Presiden dalam hal seremonial apabila Presiden berhalangan, serta menentukan ca- 
lon-calon pejabat yang menjadi ketua badan pertimbangan Jabatan Nasional (Baperjanas) (Supardi, 2019).

Fenomena Wakil Presiden sebagai ban serep sedikit mulai ditinggalkan pada masa selanjutnya yaitu pada masa Wakil Presiden B.J. Habibie. Pada masa Wakil Presiden B.J. Habibie, terjadi perubahan yang signifikan terkait dengan kewenangan jabatan Wakil Presiden. Hal ini dikarenakan kepercayaan dunia internasional terhadap Pemerintah Indonesia mulai menurun dikarenakan adanya tanda-tanda bahwa krisis ekonomi mulai tampak (Huda, 2019). Oleh karena itu, Presiden Soeharto kemudian mengumumkan tiga tugas pokok Wakil Presiden B.J. Habibie, yaitu: pertama, membantu tugas Presiden dalam tugas percaturan global terutama aktif di organisasi-organisasi internasional diantaranya: PBB, OKI, GNB, APEC, G-15, G-8, ASEAN, dan ASEM. Kedua, menyerasikan pembangunan industri yang meliputi industri hulu dan hilir, industri kecil, menengah, dan berat serta agro industri dan industri rumah tangga. Ketiga, turut membina persatuan dan kesatuan bangsa berdasarkan ketaqwaan dan keimanan kepada Tuhan Yang Maha Esa. Dengan demikian, dapat disimpulkan bahwa tugas Presiden Soeharto yang sudah lebih dari 30 tahun dilaksanakan sendirian kini mulai didelegasikan kepada Wakil Presiden B.J. Habibie. Akan tetapi, pada masa jabatan Wakil Presiden B.J. Habibi ini, Presiden Soeharto dipaksa turun dari jabatannya sebagai Presiden setelah berkuasa selama kurang lebih 32 tahun (Heryanto, 2019). Dengan demikian, maka sesuai dengan amanat konstitusi maka B.J. Habibi menggantikan Soeharto untuk menjadi Presiden Indonesia. Jika melihat dari berbagai tugas dan kewenangan yang dimiliki, maka sejatinya pada orde baru jabatan Wakil Presiden masih dominan sebagai "assistance" bagi Presiden, atau istilah lainnya dapat disebut sebagai ban serep maupun presidential complementary tentunya dengan pengecualian pada masa Wakil Presiden B.J. Habibie.

Pada era pascareformasi yang diiringi dengan semakin meluapnya aspek demokratisasi dengan jargon "Indonesia baru tanpa orba" membuat keinginan masyarakat Indonesia akan adanya pemilihan umum untuk memilih Presiden dan Wakil Presiden semakin menguat (Johan, 2018). Puncaknya, pada tahun 1999 dilaksanakanlah pemilihan umum yang berhasil memilih pasangan Presiden dan Wakil Presiden yaitu K.H. Abdurrahman Wahid dan Megawati Soekarnoputri. Dalam pemilihan umum tahun 1999 tersebut, K.H. Abdurrahman Wahid memperoleh 375 suara sedangkan Megawati Soekarnoputri hanya memperoleh 313 suara di Majelis Permusyawaratan Rakyat (Romli, 2017). Pada masa pemerintahan K.H. Abdurrahman Wahid dan Megawati Soekarnoputri kedudukan dan kewenangan Wakil Presiden mendapatkan landasan yuridis berupa Keputusan Presiden Republik Indonesia Nomor 121 Tahun 2000 Tentang Penugasan Presiden Kepada Wakil Presiden Untuk Melaksanakan Tugas Teknis Pemerintahan Sehari-Hari (selanjutnya disebut Kepres No. 121 tahun 2000).

Berdasarkan Kepres No. 121 tahun 2000 dijelaskan bahwa pelaksanaan tugas teknis pemerintahan sehari-hari meliputi: “(i) menyusun program dan agenda kerja kabinet serta menentukan fokus dan prioritas kebijakan pemerintahan, (ii) memimpin sidang kabinet, menyimpulkan hasilnya, dan menjelaskannya untuk diketahui seluruh rakyat, (iii) memberi pengarahan dan petunjuk kepada para anggota kabinet, (iv) memantau, mengawasi, dan menilai kerja para anggota kabinet dalam melaksanakan program dan agenda kerja kabinet, (v) melakukan koordinasi dengan lembaga tinggi negara lainnya untuk memperlancar tugas penyelenggaraan pemerintahan, (vi) mengambil keputusan operasional dalam rangka pelaksanaan tugas teknis pemerintahan sehari-hari, dan menandatangani surat keputusan yang berisi kebijakan penetapan yang disetujui oleh Presiden". Dengan demikian, maka terdapat pembagian tugas dan kewenangan antara Presiden dan Wakil Presiden, sehingga presiden seolaholah tidak ditempatkan sebagai ban serep atau presidential complementary. Namun, kepastian hukum kewenangan Wakil Presiden akhirnya runtuh ketika K.H. Abdurrahman Wahid dimakzulkan oleh Majelis Permusyawaratan Rakyat pada 23 Juli 2001 
(Sulistyoko, 2016) Dengan demikian, maka Wakil Presiden Megawati Soekarnoputri akhirnya ditetapkan sebagai Presiden untuk menggantikan K.H. Abdurrahman Wahid.

Megawati Soekarnoputri menjadi Presiden dengan didampingi Wakil Presiden Hamzah Haz. Di masa jabatan Wakil Presiden dipegang oleh Hamzah Haz, fenomena ban serep seperti masa Wakil Presiden sebelumnya masih terjadi. Hal ini dikarenakan, selain hanya mendampingi Presiden Megawati dalam rapat kabinet, kebijakan Hamzah Haz pun hanya berfokus pada faktor Ekonomi di mana nota bene Indonesia baru keluar dari krisis ekonomi yang menjerat pada tahun 1997-1998. Berakhirnya jabatan Presiden Megawati pada tahun 2004 mengawali babak baru demokrasi di Indonesia dengan adanya pemilihan Presiden dan Wakil Presiden secara langsung oleh rakyat (Rauta, 2014) Pemilihan umum tahun 2004 yang berlangsung secara dua putaran akhirnya menghasilkan pilihan jabatan Presiden dan Wakil Presiden Susilo Bambang Yudhoyono dan M. Jusuf Kalla.

Dalam kepemimpinan Susilo Bambang Yudhoyono dan M. Jusuf Kalla ini stigamtisasi jabatan Wakil Presiden sebagai banserep mulai sirna. Hal ini dapat dilihat secara legitimasi politik bahwa partai pengusung $M$. Jusuf Kalla yaitu Golongan Karya mendapat persentase kemennagan di pemilihan legislatif tahun 2004 sebebsar 21,58\% (24.480.757 pemilih). Hal ini justru berbanding terbalik dengan persentase partai pengusung Susilo Bambang Yudhoyono yaitu Partai Demokrat yang hanya mendapatkan 7,45\% (8.455.225 pemilih) (Nurjaman, 2018). Oleh karena itu, berdasarkan jumlah persentase perolehan suara di DPR pada pemilu 2004 tersebut, maka M. Jusuf Kalla dengan partai Golongan Karya memiliki bargaining position yang lebih tinggi daripada Susilo Bambang Yudhoyono dengan Partai Demokratnya. Hal ini lah yang berpengaruh terhadap kedudukan Wakil Presiden M. Jusuf Kalla (selanjutnya disebut JK) yang dalam masa jabatannya pernah mengeluarkan Surat Keputusan Wakil Presiden No. 1 Tahun 2004 tentang Pembentukan Tim Nasional Penanggulan- gan Bencanadi Aceh (MD, 2007). Kala itu, SK Wapres ini sebenarnya bertentangan Tap MPR Nomor III/MPR/2000 tentang Sumber Hukum dan Tata Perundang-undangan dan Undang-Undang Nomor 10 tahun 2004 tentang Pembentukan Perundang-undangan. Meski tidak dikenal dalam tertib hukum Indonesia, SK Wapres tersebut dikeluarkan atas dalih sebagai bentuk legitimasi pemerintah pada aspek teknis dalam proses penyelesaian persoalan di Aceh. Di samping itu, implikasi dari adanya SK Wapres tersebut adalah JK ditetapkan menjadi Ketua Penanggulangan Bencana Aceh. Bahkan, hadirnya SK Wapres ini membuat DPR kala itu mengajukan hak interpelasi guna meminta penjelasan kepada Wapres JK atas tindakan tersebut. Selain itu, kontribusi Wakil Presiden M. Jusuf Kalla adalah menginisiasi adanya perjanjian Helsinki 15 Agustus 2005 (Widodo, 2005) Perjanjian itu di latar belakangi adanya konflik antara pemerintah Indonesia dengan Gerakan Aceh Merdeka yang telah berjalan selama 29 tahun. Dalam memorandum of understanding tersebut, Gerakan Aceh Merdeka sepakat untuk mencabut tuntutan memisahkan diri dari Indonesia (Sudirman \& Haryanto, 2018). Sedangkan pemerintah Indonesia sepakat untuk membebaskan tahanan Gerakan Aceh Merdeka serta memperbolehkan Gerakan Aceh Merdeka sebagai salah satu partai politik guna mengisi nafas demokrasi yang telah sedang berjalan di Indonesia. Di samping itu, bermodal dengan latar belakangnya sebagai pengusaha, JK juga aktif untuk menangani berbagai problematika ekonomi di tanah air.

Fenomena jabatan Wakil Presiden sebagai ban serep telah terjadi kembali pada saat Presiden Susilo Bambang Yudhoyono memasuki periode kedua, yakni pada tahun 2009 sampai 2014. Kala itu, jabatan Wakil Presiden diduga oleh Boediono, figur sipil pertama pada era pasca reformasi (haryo ksatrio utomo, 2017). Peran Boediono terkesan hanya mengikuti perintah Preesiden. Wakil Presiden Boediono selalu memiliki pandangan dan pendapat yang sama atas kebijakan yang dikeluarkan oleh Presiden SBY. Wakil Presiden Boediono hanya melakukan praktik ketatanegaraan manakala Presiden SBY berhalangan hadir, seperti halnya me- 
mimpin rapat kabinet, mengevaluasi kinerja kabinet, menyusun agenda kerja dari berbagai Kementerian, memberikan araham kepada berbagai lembaga pemerintahan, dan lain sebagainya. Dapat disebut bahwa peran Boediono hanyalah sebagai penunjang dari beberapa narasi politik yang digaungkan oleh Pemerintah, khususnya Presiden SBY.

Lima tahun berselang, JK kembali menduduki jabatan wakil presiden untuk mendampingi Joko Widodo sebagai Presiden pada periode 2014-2019. Pada era kali ini, JK menolak menjadi ban serep dengan memberikan peran lebih aktif dalam aspek politik luar negeri Indonesia. Kala itu, pola diplomasi yang diterapkan oleh JK adalah "tangan diatas", yakni pemerintah Indonesia siap sedia untuk memberikan berbagai bantuan kepada negara lain, khususnya negara berkembang. Bukan itu saja, JK juga selalu turut serta dalam sidang umum tahunan Perserikatan Bangsa Bangsa, hadir dalam pertemuan G20 (Lisbet, 2018), ikut serta dalam KTT APEC dan KTT Asia Eropa, konferensi penanganan bencana di Swiss, serta menjadi wakil Indonesia di KTT ASEAN di Malaysia. Bahkan, pada periode ini JK menjadi salah satu inisiator pendirian Indonesia AID, lembaga pemerintah yang memiliki tugas guna menyalurkan dana bantuan kepada negaranegara lain guna mengentaskan kemiskinan serta kesenjangan sosial. Jiwa internasionalisme dari diri JK inilah yang memberikan legitimasi cukup baik bagi negara Indonesia pada panggung internasional.

Pada tahun 2019, Joko Widodo terpilih kembali menjadi Presiden didampingi oleh K.H. Ma'ruf Amin sebagai Wakil Presiden. Di masa kepemimpinan Joko WidodoK.H. Ma'ruf Amin kedudukan Wakil Presiden sebagai ban serep dikarenakan K.H. Ma'ruf Amin hanya menjalankan tugas-tugas seremonial serta dilihat dari legitimasi politik, K.H. Ma'ruf Amin tidak memiliki bargaining position yang kuat serta hanya sebagai salah satu sarana pendulang suara dalam Pemilihan Presiden 2019. Dengan demikian, dapat disimpulkan bahwa system presidensial dengan kombinasi multipartai bisa berdampak pada relasi Presiden dan Wakil Presiden se- bagaimana telah diuraikan sebelumnya secara historis.

\section{Ius Constituendum Kedudukan dan Kewenangan Wakil Presiden}

Jabatan Wakil Presiden merupakan salah satu jabatan yang sentral dalam sistem presidensial (Suny, 1986) Hal ini dapat dimengerti karena dalam sistem presidensial eksekutif dalam hal ini Presiden dan Wakil Presiden memiliki kedudukan yang strategis serta sebagai lembaga pelaksana kekuasaan untuk melaksanakan suatu Undang-Undang yang telah disepakati dengan parlemen (Suny, 1986). Jabatan Wakil Presiden berdasarkan sistem ketatanegaraan Indonesia baik sebelum maupun sesudah perubahan konstitusi sejatinya tidaklah tepat untuk ditempatkan lebih "inferior" dibandingkan dari jabatan Presiden itu sendiri. Hal ini juga menimbulkan ironi, di mana sebagai pemegang pemerintahan nomor dua di lingkungan eksekutif, jabatan Wakil Presiden justru tidak memiliki kekuasaan yang melekat dan bersifat pasti, jika dibandingkan dengan pembantu Preisden yang berupa menteri-menteri negara yang memiliki kewenangan yang bersifat pasti, maka kewenangan Wakil Presiden yang belum memiliki kepastian hukum dapat dikatakan masih menjadi problematika tersendiri yang seyogyanya harus diselesaikan (Huda, 2019).

Salah satu pendekatan yang menempatkan kedudukan Presiden dan Wakil Presiden setara adalah pendekatan yang dilakukan oleh Kuntana Magnar dan Bagir Manan (Zaman, 2018)' yang menyatakan bahwa tidak ada hubungan hierarkis antara Presiden dan Wakil Presiden sehingga tidaklah tepat kalau hubungan Presiden dan Wakil Presiden seperti halnya atasan dan bawahan (Zaman, 2018). Hubungan yang tepat antara Presiden dan Wakil Presiden adalah hubungan sejajar dalam melaksanakan kekuasaan pemerintahan (tentunya dalam arti sempit) di mana dalam hal ini ditempatkan bahwa Presiden sebagai the first man atau pemegang prioritas pertama sedangkan Wakil Presiden sebagai the second man atau prioritas kedua. Dengan demikian, dapat disimpulkan bahwa antara Presiden dan Wakil Presiden secara kedudu- 
kan adalah sejajar, namun yang membedakannya hanyalah pada pembagian kewenangan dalam melaksanakan pemerintahan.

Jabatan Presiden dan Wakil Presiden sebagaimana di bahas pada pembahasan sebelumnya di masa awal kemerdekaan dapat dikatakan sebagai suatu "dwitunggal" (R. A. B. Kusuma, 2011). Konsepsi "dwitunggal" Presiden Soekarno dan Wakil Presiden Moh. Hatta merupakan kpnsepsi yang menekankan adanya kedudukan yang sejajar dan sederajat antara Presiden dan Wakil Presiden. Selain itu, konsepsi "dwitunggal" secara politis juga dimaknai sebagai representasi perwakilan dari pemimpin (dalam hal ini Presiden dan Wakil Presiden) yaitu Presiden Soekarno diidentikkan sebagai perwakilan dari Jawa sedangkan Wakil Presiden Moh. Hatta diidentikkan sebagai perwakilan dari luar Jawa (Surayah Rashid, 2017).

Secara sitem ketatanegaraan, konsepsi "dwitunggal" dimaknai sebagai pengejawentahan akan kehendak the founding leaders untuk mebentuk sistem tersendiri dalam sistem ketatanegaraan Indonesia pada awal kemerdekaan (R. M. A. B. Kusuma, 2010). Sistem sendiri dimaksudkan bahwa Indonesia tidak menganut sistem presidensialisme secara mutlak, namun menyesuaikan dengan keadaan serta kultur bangsa Indonesia. Istilah system sendiri sejatinya dikemukakan karena pada tahun 1945 bemum terdapat istilah hybrid system atau mixed system. Dengan demikian, maka untuk mempermudah penyebutan maka dipakailah istilah sistem sendiri. Sistem sendiri yang dianut oleh Indonesia pada awal kemerdekaan sejatinya memiliki perbedaan mendasar dengan sistem presidensial pada umumnya diantaranya bahwa sistem sendiri tidak menggunakan trias politica sedangkan sistem presidensialisme di Amerika Serikat menggunakannya (Huda, 2019). Selain itu, sistem sendiri juga menganut eksekutif ganda (dual excecutieve) yang menempatkan Presiden dan Wakil Presiden sebagai "dwitunggal" tidak sebagaimana penerapan di Amerika Serikat, di mana Wakil Presiden ditempatkan sebagai ban serep atau presidential complementary. Dengan demikian maka dapat disimpulkan bahwa jabatan
Wakil Presiden tergantung pada praktik ketatanegaraan yang sedang dijalankan pada saat itu, sehingga konsistensi kedudukan dan kewenangan Wakil Presiden sepenuhnya tergantung pada praktik ketatanegaraan.

Praktik ketatanegaraan merupakan suatu perbuatan yang dilakukan oleh organorgan kekuasaan negara dalam melaksanakan fungsi dan kewenangannya (Ghunarsa Sujatnika, 2017). Dalam melaksanakan fungsi dan wewenangnya terkadang tidak ada suatu aturan di dalam konstitusi maupun UndangUndang terkait yang secara expressive verbis menegaskan bagaimana mekanisme pelaksanaannya. Di sinilah kemudian, praktik ketatanegaraan berupaya untuk melakanakan fungsi dan kewenangan organ-organ negara yang dalam kondisi dan situasi tertentu tidak diatur secara tegas dalam konstitusi. Meski pun memiliki implikasi yang baik dalam sistem ketatanegaraan Indonesia, namun praktik ketatanegaraan tetaplah tidak dapat dijadikan sebagai pedoman dasar dalam melaksanakan suatu kewenangan dari organ negara. Hal ini dikarenakan, meski pada peruntukannya praktik ketatanegaraan membuat konstitusi menjadi lebih hidup (living constitution) ( $\mathrm{Ha}-$ jri \& Rahdiansyah, 2017), namun praktik ketatanegaraan bersifat temporal dan subjektif sehingga antar satu kurun waktu kepemimpinan dengan kepemimpinan selanjutnya dapat berubah-ubah. Hal ini lah yang sekiranya dapat berakibat pada tidak adanya kepastian hukum yang dapat dipegang (atau setidak-tidaknya dijadikan dasar) terkait dengan kewenangan Wakil Presiden yang terlalu bergantung kepada praktik ketatanegaraan. Dengan demikian, menyerahkan kewenangan Wakil Presiden semata-mata kepada praktik ketatanegaraan sama halnya membiarkan jabatan Wakil Presiden sebagai ban serep sebagaimana dalam konsep single executieve di Amerika Serikat. Kewenangan Wakil Presiden yang seyogyanya diberikan secara expressive verbis dalam suatu Undang-Undang tertentu juga diharapkan dapat meminimalisasi adanya faktor-faktor non-hukum yang seringkali lebih determinan daripada faktor hukum dalam kaitannya dengan kewenangan Wakil Presiden. Hal ini dapat dilihat bahwa determinannya faktor politik dalam praktik keta- 
tanegaraan dapat berpengaruh secara signifikan terhadap kewenangan Wakil Presiden. Hal ini dikarenakan, supaya dapat memiliki kewenangan yang presisi dan proporsional, seorang Wakil Presiden haruslah memiliki bargaining position politik yang lebih tinggi (atau setidak-tidaknya sama) dengan Presiden. Hal ini dapat dicontohkan dalam kedudukan Wakil Presiden JK saat berpasangan dengan Presiden Susilo Bambang Yudhoyono pada pemilu 2004 sebagaimana telah dijelaskan sebelumnya yang begitu kuat dan berpengaruh terhadap jalannya pemerintahan. Hal ini karena partai pengusung JK, yaitu partai Golkar memiliki bargaining position tinggi yang dibuktikan dengan jumlah kursi legislatif yang dikuasai Golkar sebesar 21,58\% yang tentunya lebih tinggi dari jumlah kursi legislatif partai pengusung Presiden Susilo Bambang Yudhoyono yang hanya sebesar 7,45\%. Contoh lainnya adalah pada masa pemerintahan Presiden Joko Widodo dan Wakil Presiden K.H. Ma'ruf Amin, di mana partai pengusung Presiden Joko Widodo yaitu PDI Perjuangan menempati pole position dalam perolehan kursi di legislatif. Hal ini jelas berbanding terbalik dengan Wakil Presiden K.H. Ma'ruf Amin yang sebelumnya hanya pernah menjabat menjadi Ketua MUI pada tahun 2015, meski pun sebelumnya pernah menjabat sebagai anggota DPR pada 1999-2004. Namun, pengalaman dalam bidang politik praktis tidaklah cukup tanpa disertai dengan bargaining position yang tinggi dibuktikan dengan berapa jumlah suara partai politik yang memenangkan kursi legislatif. Akibatnya, Wakil Presiden K.H. Ma'ruf Amin tidak lebih hanya menjadi ban serep bagi Presiden Joko Widodo. Dengan demikian, maka kewenangan Wakil Presiden tidak diperbolehkan apabila hanya bergantung pada praktik ketatanegaraan saja, melainkan harus diberi aspek kepastian hukum yang lebih memadai supaya kewenangan Wakil Presiden tidak tergantung pada bargaining position dari partai politik pengusung.

Kewenangan Wakil Presiden bila ditinjau dari perpektif yuridis tidak dapat diinferiorkan dengan kewenangan Presiden yang secara expressive verbis tercantum dalam konstitusi. Hal ini dikarenakan, jika ditinjau dalam teori kewenangan maka kewenangan yang sering disebut sebagai gezag atau authority merupakan kekuasaan yang diinformalkan yang berimplikasi pada segolongan orang tertentu yang berlaku bulat dalam suatu bidang pemerintahan (Zaman, 2018). Dalam Black Law Dictionary kewenangan diartikan sebagai "legal power a right to command or to act the right and power of public officers to require obedience to thir orders laufully issued in scope of their public duties." Pengertian kewenangan juga dapat dibedakan dengan pengertian wewenang yang dapat dipahami sebagai kemampuan untuk melakukan suatu tindakan hukum publik yang diberikan oleh Undang-Undang guna melaksanakan suatu hubungan hukum yang bersifat tertentu (Zaman, 2018). Dengan demikian, maka kewenangan dapat disebut sebagai kumpulan dari berbagai wewenang. Jika berkaca dari konsep kewenangan tersebut maka kewenangan haruslah bersifat pasti yang salah satunya dibuktikan dengan adanya suatu Undang-Undang yang mengatur. Dengan demikian, jika dikaitkan dengan kewenangan Wakil Presiden maka diperlukan pengaturan tertentu di Undang-Undang lembaga kepresidenan yang isinya membagi kewenangan antara Presiden dan Wakil Presiden. Hal ini dapat dilakukan sebagaimana dalam Kepres No. 121 tahun 2000 pada zaman Presiden K.H. Abudurrahman Wahid.

Pembagian kewenangan antara Presiden dan Wakil Presiden dalam Undang-Undang Lembaga Kepresidenan diharapkan juga memberikan kedudukan yang sama kuatnya antara Presiden dan Wakil Presiden. Pengalaman dari beberapa negara telah memberikan kedudukan yang kuat dan tegas terhadap kewenangan Wakil Presidennya. Hal ini misalnya dicontohkan oleh Amerika Serikat yang sebelumnya disebutkan melaksanakan konsep single execuutieve di mana Wakil Presiden didudukkan sebagai ban serep namun memberikan kedudukan yang tinggi kepada Wakil Presiden yaitu sebagai ketua senat (Mochamad Isnaeni Ramadhan, 2015) Hal ini dapat dibuktikan dalam Article one section three konstitusi Amerika Serikat bahwa, "The vice president of the united states shall be president of the senate, but shall have no 
vote, unless they be equally divided". Oleh karena itu, Wakil Presiden di Amerika Serikat memiliki kedudukan yang kuat. Di beberapa negara lain selain sebagai pengganti Presiden (Vice President) Wakil Presiden juga ada yang menduduki anggota parlemen sebagaimana yang terjadi di India. Selain itu, beberapa diantaranya juga menjadi anggota cabinet sebagaimana yang terjadi di Afrika Selatan, Filipina, dan Irak. Dengan demikian, dapat disimpulkan bahwa penguatan kedudukan dan kewenangan Wakil Presiden diperlukan untuk menjamin supaya Wakil Presiden tidak hanya ditempatkan sebagai ban serep bagi Presiden. Selain itu, pembagian kewenangan yang proporsional seyogyanya diatur dalam Undang-Undang Lembaga Kepresidenan diharapkan dapat mempertegas serta dapat mengefektifkan kinerja Presiden dan Wakil Presiden.

\section{Simpulan}

Praktik ketatanegaraan Indonesia terkait kewenangan Wakil Presiden masih menggantungkan aspek non-hukum seperti halnya aspek politik. Jika Wakil Presiden merupakan kader atau ditunjuk oleh partai politik yang mempunyai bargaining position tinggi, maka Wakil Presiden tersebut akan memiliki kedudukan dan kewenangan yang kuat. Sebaliknya, jika Wakil Presiden tidak memiliki bargaining position tinggi maka Wakil Presiden hanya menjadi presidential complementary atau ban serep bagi Presiden. Hal ini dapat dilihat dalam sejarah ketatanegaraan Indonesia di mana faktor praktik ketatanegaraan yang tidak konsisten dan dapat berubah serta faktor non hukum seperti halnya politik lebih determinan dan mendominasi kedudukan dan kewenangan Wakil Presiden sehingga seolah-olah Wakil Presiden hanya sebagai ban serep bagi Presiden.

Kewenangan Wakil Presiden yang masih bergantung pada praktik ketatanegaraan serta faktor non hukum yaitu faktor politik telah menyebabkan ketidakkonsistenan pelaksanaan kewenangan Wakil Presiden. Oleh sebab itu, untuk menjamin kepastian hukum akan kedudukan dan kewenangan Wakil Presiden maka diperlukan pembagi- an kewenangan antara Presiden dan Wakil Presiden dalam pelaksanaan pemerintahan. Hal tersebut dapat optimal apabila pembagian kewenangan antara Presiden dan Wakil Presiden diatur dalam Undang-Undang Lembaga Kepresidenan yang bersifat pasti serta tidak tergantung pada praktik ketatanegaraan maupun faktor non hukum lainnya terutama faktor politik.

Mengingat fungsi Wakil Presiden yang sangat strategis dalam sistem presidensiil, maka alangkah baiknya jika Undang-Undang Lembaga Kepresidenan segera dibentuk agar ada kepastian hukum terkait dengan fungsi Wakil Presiden. Dalam sistem ketatanegaraan RI, Undang-Undang memiliki posisi yang sangat strategis dalam rangka mengatur pembagian wewenang antar Presiden dan Wakil Presiden. Dengan segera terbentuknya Undang-Undang Lembaga Kepresidenan, maka posisi Wakil Presiden akan menjadi stabil tanpa terpengaruh oleh konfigurasi politik yang seringkali berubah.

\section{Daftar Pustaka}

Arsil, F. (2017). Teori Sistem Pemerintahan (1st ed.). PT RajaGrafindo Persada.

Atmakusumah (Ed.). (2011). Tahta Untuk Rakyat: CelahCelah Kehidupan Sultan Hamengku Buwono IX (4th ed.). PT Gramedia Pustaka Utama.

Fiky Arista, S. dan F. S. (2017). Perbandingan Kebijakan Adam Malik, Mochtar Kusumaatmadja Dan Ali Alatas Terhadap Politik Luar Negeri Bebas Aktif Indonesia Pada Masa Orde Baru. Factum, 6(1), 77. https://doi.org/10.1017/ CBO9781107415324.004

Fuqoha, F. (2018). Pengisian Jabatan Presiden dan Presidential Threshold dalam Demokrasi Konstitusional di Indonesia. Ajudikasi : Jurnal IImu Hukum, 1(2), 27-38. https://doi.org/10.30656/ ajudikasi.v1i2.495

Ghunarsa Sujatnika. (2017). Pengaruh Konstitusi Berketuhanan Dalam Praktik Ketatanegaraan (Perbandingan Antara Indonesia Dengan Berbagai Negara). Hukum Dan Pembangunan, 48(4), 1689-1699. https://doi.org/10.1017/ CBO9781107415324.004

Hajri, W. A., \& Rahdiansyah, R. (2017). "Menghidupkan" Undang-Undang Dasar 1945 Tanpa Amandemen. Jurnal Hukum lus Quia lustum, 24(4), 558-576. https://doi.org/10.20885/iustum.vol24.iss4.art3

Haris, S. (Ed.). (2019). Menimbang Demokrasi Dua Dekade Reformasi (1st ed.). Yayasan Pustaka Obor Indonesia.

Haryo, K.U. (2017). dan Pengesahan RUU tentang Badan Pengelola Jaminan Sosial ( BPJS ). Jurnal 
Hananto Widodo, et al., Relasi Kekuasaan Antar Presiden dan Wakil Presiden dalam Sistem Ketatanegaraan...

Politik, 3(1).

Heryanto, G. G. (2019). Literasi Politik: Dinamika Konsolidasi Demokrasi Indonesia Pascareformasi (1st ed.). IRCiSoD.

Huda, N. (2019). Presiden dan Pembantu Presiden dalam Sistem Ketatanegaraan Indonesia (1st ed.). UII Press.

Johan, T. S. B. (2018). Hukum Tata Negara dan Hukum Administrasi Negara dalam Tataran Reformasi Ketatanegaraan Indonesia (1st ed.). Deepublish.

Kusuma, R. A. B. (2011). Sistem Pemerintahan Pendiri Negara Versus Sistem Presidensiel Orde Reformasi (1st ed.). Badan Penerbit Fakultas Hukum Universitas Indonesia.

Kusuma, R. M. A. B. (2010). Sistem Pemerintahan Sebelum dan Sesudah Amandemen. Konstitusi, 1(1), 11-12.

Lisbet. (2018). Isu Penting di KTT G-20 dan Peran Ri dalam Penguatan Multilateralisme. Info Singkat DPR RI, 10(23).

Marijan, K. (2019). Sistem Politik Indonesia: Konsolidasi Demokrasi Pasca Orde Baru (6th ed.). Kencana.

Marzuki, P. M. (2017). Penelitian Hukum: Edisi Revisi (13th ed.). KENCANA.

MD, M. M. (2007). Hukum Tak Kunjung Tegak. Citra Aditya Bakti.

Melania M.I. Wongkar. (2016). Kajian Hukum Pengaturan Pemberhentian Presiden/Wakil Presiden dalam Masa Jabatan Berdasarkan UUD 1945. Lex et Societatis, IV(8), 76-77. https://doi. org/10.1016/j.cya.2015.11.011

Mochamad, I.R. (2015). Jabatan Wakil Presiden Menurut Hukum Tata Negara Indonesia. Sinar Grafika.

Mulyanti, D. (2018). Rekonstruksi Jabatan Wakil Presiden Dalam Ketatanegaraan Di Indonesia (Tinjauan Perbandingan Hukum Negara Amerika Serikat, Cina Dan Filipina). Jurnal Ilmiah Galuh Justisi, 6(1), 64. https://doi.org/10.25157/jigj. v6i1.1241

Nurjaman, A. (2018). Sistem Kepartaian Indonesia (1st ed.). UMMPress.

Nyoman Mas Aryani, B. H. (2018). Rekonstruksi Kejelasan Kedudukan Wakil Presiden dalam Kerangka Penguatan dan Penegasan Sistem Presidensii Indonesia. Legislasi Indonesia, 15(02), 91-101.

Rauta, U. (2014). Menggagas Pemilihan Presiden yang Demokratis dan Aspiratif. Jurnal Konstitusi, 11(3), 1-17. https://doi.org/10.1186/s40779016-0093-2
Reformulasi, T., Ham, K., Miladmahesi, R., \& M, A. D. S. (2019). Evaluasi Peran Penegakan Hukum oleh Lembaga Negara Penunjang ( State Auxiliary Bodies ). Teropong, 7(1).

Romli, L. (2017). Koalisi dan Konflik Internal Partai Politik pada Era Reformasi Coalition and Internal Party Conflicts of Reform Era in Indonesia. POlitica, 8(2), 95-118.

Siregar, S. N. (Ed.). (2018). Sistem Presidensial Indonesia dari Soekarno ke Jokowi. Yayasan Pustaka Obor Indonesia.

Sudirman, A., \& Haryanto, N. N. (2018). Upaya Disaster Diplomacy Pemerintah Indonesia Di Konflik Aceh Tahun 2005. Sosiohumaniora, 20(3), 269. https://doi.org/10.24198/sosiohumaniora. v20i3.15586

Sulistyoko, A. (2016). Pemakzulan Presiden dalam Persepsi Konstitusi (Studi Kasus Presiden Abdurrahman Wahid). Syariah, 16(1), 47-75.

Suny, I. (1986). Pergeseran Kekuasaan Eksekutif (6th ed.). Aksara Baru.

Supardi, S. (2019). Optimalisasi Jabatan Wakil Presiden Menurut Undang-Undang Dasar 1945 PascaAmandemen. ljtihad, 34(2), 161-176. https:// doi.org/10.15548/ijt.v34i2.15

Surayah Rashid. (2017). Permesta Menggugat. Al Hikmah, 19(2), 119-134.

Susanto, M. (2017). Wacana Mengembalikan Syarat Presiden Orang Indonesia Asli Ditinjau dari Perspektif Ketatanegaraan. Jurnal Ilmiah Kebijakan Hukum, 12(2), 193-204. https://doi.org/http:// dx.doi.org/10.30641/kebijakan.2017.V11.193204

Suwirta, A. R. and. (2018). Kiprah Sudharmono Dalam Sejarah Golongan Karya (1983-1988). Factum, 7(2), 133-144.

Syaputra, D. (2018). Kewenangan Presiden, DPR dan DPD Dalam Pembentukan Undang-Undang di Republik Indonesia. Jurnal Menara IImu, XII(4), 29-38.

Thoha, M. (2014). Birokrasi Politik dan Pemilihan Umum di Indonesia. Kencana.

Triono. (2017). Menakar Efektivitas Pemilu Serentak 2019. Jurnal Wacana Politik, 2(2), 156-164. https://doi.org/10.24198/jwp.v2i2.14205

Widodo, H. (2005). Aspek Ketatanegaraan MoU RIGAM (p. 4). Surabaya Post.

Zaman, N. (2018). Rekonstruksi Kekuasaan Wakil Presiden dalam Sistem Pemerintahan di Indonesia (1st ed.). Refika Aditama. 